УДК 519.6

\title{
Liquid oscillation in a cylindrical-conical shell under the action of vertical and horizontal excitation
}

\author{
${ }^{1}$ V.Y.Kylynnyk, ${ }^{2}$ D.V.Kriutchenko, ${ }^{2}$ Y.V.Naumenko \\ ${ }^{1}$ V. N. Karazin Kharkiv National University, 4 Svobody Sq., Kharkiv, 61022, Ukraine \\ ${ }^{2}$ A. Pidgorny Institute of Mechanical Engineering Problems of the National Academy of Sciences, \\ vul. Pozharskogo, 2/10, Kharkiv, 61046, Ukraine; \\ email:vladakylynnyk@gmail.com;
}

\begin{abstract}
Vibrations of an ideal incompressible fluid in shells of revolution have been considered. The shells of revolution under consideration include cylindrical and conical parts. It is assumed that the shell is subjected to vertical and horizontal excitations. The liquid in the shells is supposed to be an ideal and incompressible one. The fluid flow is the irrotational. Therefore the velocity potential that satisfies the Laplace equation exists. The non-penetration conditions are applied to the wetted surfaces of the shell and the kinematic and dynamic conditions on the free surface have been considered. The liquid pressure as the function of the velocity potential is defined using the Bernoulli equation. The problem of determining the fluid pressure is reduced to solving a singular integral equation. The numerical solution of the equation has been obtained by the method of discrete singularities. The method of simulating the free and forced oscillations of the fluid in the shells of revolution has been developed.
\end{abstract}

Key words: compound shells of revolution, ideal incompressible fluid, methods of boundary elements and discrete singularities, frequencies and modes of vibrations.

Розглядаються коливання ідеальної нестисливої рідини в оболонках обертання. Рух рідини являється безвихровим, i розглядаються лише невеликі коливання цієї рідини(лінійна теорія). Оболонки включають циліндричну та конічну частини. Передбачається, що оболонка піддається вертикальним та горизонтальним збудженням. Сформульовані граничні умови для розв'язання рівняння Лапласа. На змоченій поверхні оболонки застосовуються умови непротікання, а на вільній поверхні розглядаються кінематичні та динамічні умови. . Існує потенціал швидкості, який задовольняє рівнянню Лапласа. Тиск рідини як функція потенціалу швидкості визначається за допомогою лінеаризованого рівняння Бернуллі для потенційного потоку. Проблема визначення тиску рідини зводиться до розв'язання сингулярного інтегрального рівняння. Числове рішення цього рівняння отримано за допомогою метода дискретних особливостей. Ядра інтегральних рівнянь містять повні еліптичні інтеграли першого та другого виду. Еліптичний інтеграл другого виду обчислюється за допомогою стандартної квадратичної формули Гаусса. Для еліптичного інтеграла першого виду застосовується підхідна основа на характерні властивості середнього арифметичного геометричного значення AGM. Зовнішні інтеграли мають які мають логарифмічну особливість обчислюються за допомогою спеціальної квадратурної формули Гаусса. Отримано незв'язану систему диференціальних рівнянь Матьє другого порядку. Розроблено метод дослідження вільних і вимушених коливань рідини в оболонках оберту. Розроблено метод оцінки вимушених коливань рідини в оболонках обертання, заснований на використанні методу граничних інтегральних рівнянь та розкладу ряду Фур'є. Аналіз результатів показав, що спостерігається явище параметричного резонансу. Розглянуто сумарний вплив вертикальних і горизонтальних збуджень.

Ключові слова: складені оболонки оберту, ідеальна нестислива рідина, методи граничних елементів та дискретні особливості, частоти та форми коливань.

Рассматриваются колебания идеальной несжимаемой жидкости в оболочках вращения. Эти оболочки состоят из цилиндрической и конической частей. Предполагается, что оболочка подвергается вертикальным и горизонтальным возбуждением. Жидкость в оболочках рассматривается идеальная и несжимаемая. Ее движение в оболочке предполагается безвихревым. В этих условиях существует потенциал скоростей, который удовлетворяет уравнению Лапласа. На смоченной поверхности оболочки задается условие непротекания, а на свободной поверхности рассматриваются кинематические и динамические условия. Давление жидкости как функция потенциала скорости определяется с помощью уравнения Бернулли. Проблема определения давления жидкости сводится к решению сингулярного интегрального уравнения. Численное решение этого уравнения осуществляется с помощью метода дискретных особенностей. Разработан метод расчета свободных и вынужденных колебаний жидкости в оболочках вращения.

Ключевые слова: составные оболочки вращения, идеальная несжимаемая жидкость, методы граничных элементов и дискретных особенностей, частоты и формы колебаний.

\section{Introduction}

Shell structures for storage and transportation of fluid are the subject of numerous scientific researches. These shell structures are important for power plants, pumps, columns of oil evaporators, and other industrial constructions. There are a large number of various strength and vibration problems for shell structures that have been examined in recent decades. 
The overview of scientific works has shown that many articles are focused on the problem of intense liquid sloshing in containers and fuel tanks. The overview on the problem of fluid splashing in cylindrical, conical and spherical reservoirs is presented in the works of R. A. Ibrahim [1,2]. On the other hand, shells consisting of cylindrical and conical parts have received less attention in the scientific literature although such thin-walled structures are widely used in various installations. A review of researches on this topic $[2,3]$ shows that the dynamic characteristics of the reservoirs are significantly influenced by fluid sloshing and oscillations of the elastic walls. Free and forced oscillations of cylindrical reservoirs with a liquid are examined in [4-7]. It should be noted that the majority of studies do not take into account the impact of the force of gravity causing sloshing.

\section{Formulation of the problem.}

The problem of oscillation of a fluid in a compound rotation shell having cylindrical and conical parts has been considered. The moistened part of the surface of the shell is denoted as $S_{1}$ and the free surface as $S_{0}$. Furthermore, it is suggested that the Cartesian coordinate system Oxyz is bound to the shell, the free surface coincided with the plane $\mathrm{z}=\mathrm{H}=\mathrm{H}_{1}+\mathrm{H}_{2}$ at state of rest (Fig. 1).

We assume that $\mathrm{H}_{1}$ is the length of the cylindrical part, and $\mathrm{H}_{2}$ is the height of the conical part, $\mathrm{R}_{1}$ and $\mathrm{R}_{2}$ are the radii of the lower and upper parts of the shell, Fig. 2.1.

The mathematical model for the fluid-occupied region is based on the following hypotheses: fluid is incompressible and non-dissipative, fluid motion is non-vortex, and only small fluctuations are considered (linear theory). Therefore, we could enter the scalar potential of velocities $\Phi(\mathrm{x}, \mathrm{y}, \mathrm{z}, \mathrm{t})$ which satisfy the Laplace equation. The fluid pressure $p=p(x, y, z, t)$ which acts on the wetted surface is obtained from the linearized Bernoulli equation for the potential flux

$$
p-p_{0}=\rho_{l}\left[\frac{\partial \Phi}{\partial t}+x a_{x}(t)+z\left(g+a_{z}(t)\right)\right],
$$

where $g$ is gravitational acceleration, $\mathrm{z}$ is vertical coordinate of the point in the fluid, $p_{l}$ is a density of fluid, $p_{0}$ is an atmospheric pressure, $a_{z}(t)=a_{0} \cos \omega t$ is a vertical acceleration of the excitatory force, $a_{x}(t)=a_{1} \cos \omega t$ is a horizontal acceleration of the excitatory force, $a_{0}$ is an amplitude of the forced influence.

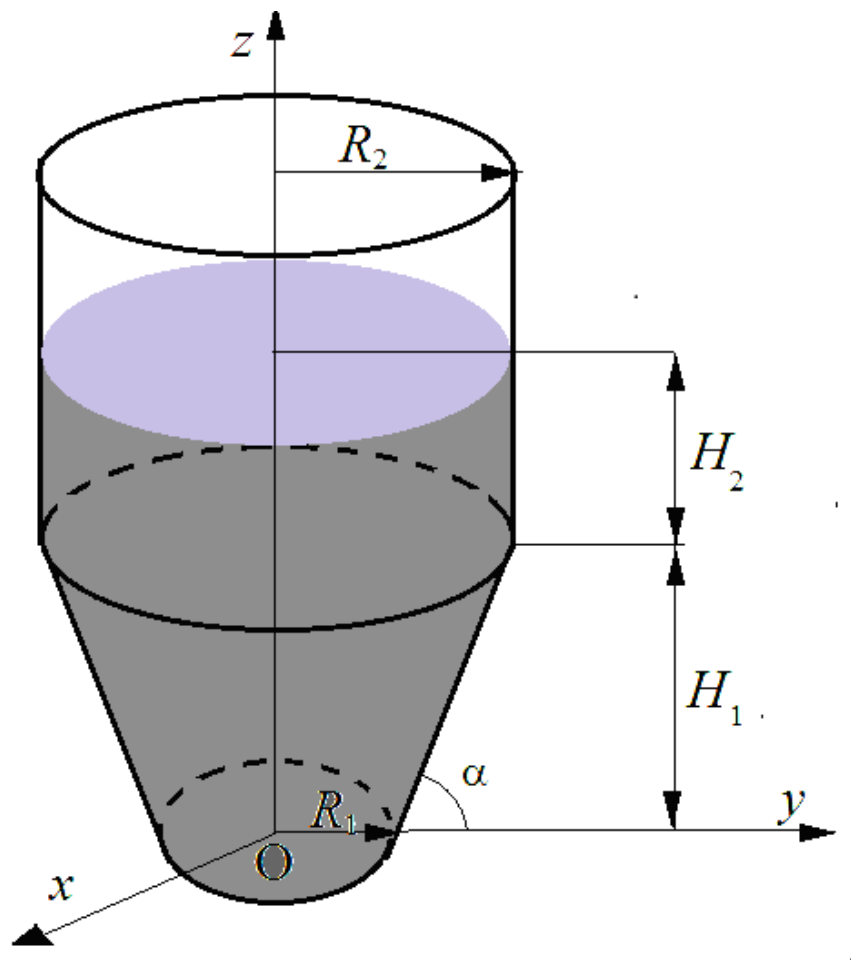

Figure2.1. Shell rotation with fluid and the forms of oscillations of free surface 
It should be noted that the assumption of flow potential is quite natural since, according to Kelvin's theorem, if the motion of an ideal incompressible fluid is potential at an initial moment, it will remain potential throughout the next period of motion.

First of all let us consider the problem of the shell free oscillations. We have formulated the boundary conditions for solving the Laplace equation. On the wetted surfaces of the shell, the boundary impermeability condition have been set [8]. The following boundary conditions have to be satisfied on the free surface of the liquid:

$$
p-\left.p_{0}\right|_{S_{0}}=0,\left.\frac{\partial \Phi}{\partial \mathbf{n}}\right|_{S_{0}}=\frac{\partial \zeta}{\partial t}
$$

where $\boldsymbol{n}$ is a unit outer normal to the surface $S_{0}$. Function $\zeta$ describes the shape and position of the free surface. The first of these conditions is dynamic one and states that the pressure on the liquid surface equals atmospheric pressure. The second condition is kinematic and means that points on the free surface at the initial moment of motion remain on it thereafter.

Having made the transformations at the specified boundary conditions, similar to [8] to find the velocity potential in the problem of free oscillations of a liquid, we have the following boundary value problem:

$$
\Delta \Phi=0,\left.\frac{\partial^{2} \Phi}{\partial t^{2}}\right|_{S_{0}}+\left.g \frac{\partial \Phi}{\partial \mathbf{n}}\right|_{S_{0}}=0,\left.\frac{\partial \Phi}{\partial \mathbf{n}}\right|_{S_{1}}=0 .
$$

Here $\mathbf{n}$ is an outer unit normal to the surface under consideration.

In order to fulfill the conditions of solvability of the boundary-value problem, the Neumann condition must be satisfied [8]:

$$
\int_{S_{0}} \frac{\partial \Phi}{\partial \mathbf{n}} d S_{0}=0
$$

Thus, a mixed boundary value problem for the Laplace equation is formulated.

\section{The main research material}

Consider the potential $\Phi$ in representation of the series.

$$
\Phi=\sum_{k=1}^{M} \dot{d}_{k}(t) \varphi_{k} .
$$

The modes $\varphi_{k}$ are solutions of boundary-value problem (2.2) which, according to [3,8], becomes the problem of eigenvalues. To define functions $\varphi_{k}$, we use the direct formulation of the boundary element method. The main integral relation is presented in the form [9]

$$
2 \pi \Phi\left(\mathrm{P}_{0}\right)=\iint_{\mathrm{S}} \frac{\partial \Phi}{\partial \mathbf{n}} \frac{1}{\left|\mathrm{P}-\mathrm{P}_{0}\right|} \mathrm{d} \mathrm{S}-\iint_{\mathrm{S}} \Phi \frac{\partial}{\partial \mathbf{n}} \frac{1}{\left|\mathrm{P}-\mathrm{P}_{0}\right|} \mathrm{d} S, \mathrm{~S}=\mathrm{S}_{0} \cup \mathrm{S}_{1},
$$

where $S=S_{1} \cup S_{0}$; points $P$ and $P_{0}$ belong to the surface $S .\left|P-P_{0}\right|$ denote the Cartesian distance between points $P$ i $P_{0}$. Functions $\Phi$, which is defined on the surface $S_{1}$, is the pressure on the wetted surface, and the function $=\frac{\partial \Phi}{\partial \boldsymbol{n}}$, that is defined on $S_{0}$, is a flow . Using boundary conditions

$$
\left.\frac{\partial^{2} \Phi}{\partial t^{2}}\right|_{S_{0}}+\left.g \frac{\partial \Phi}{\partial \mathbf{n}}\right|_{S_{0}}=0,\left.\frac{\partial \Phi}{\partial \mathbf{n}}\right|_{S_{1}}=0
$$

and assuming that $\Phi(x, y, z, t)=\exp (i \chi t) \varphi(x, y, z, t)$, we obtain a system of singular integral equations in the form $[7,10]$

$$
\left\{\begin{array}{c}
2 \pi \varphi+\iint_{S_{1}} \varphi \frac{\partial}{\partial \mathbf{n}}\left(\frac{1}{\left|P-P_{0}\right|}\right) d S-\frac{\chi^{2}}{g} \iint_{S_{0}} \varphi_{0} \frac{1}{\left|P-P_{0}\right|} d S+\iint_{S_{0}} \varphi_{0} \frac{\partial}{\partial \mathrm{z}}\left(\frac{1}{\left|P-P_{0}\right|}\right) d S=0 \\
-\iint_{S_{1}} \varphi \frac{\partial}{\partial \mathbf{n}}\left(\frac{1}{\left|P-P_{0}\right|}\right) d S-2 \pi \varphi_{0} \frac{\chi^{2}}{g} \iint_{S_{0}} \varphi_{0} \frac{1}{\left|P-P_{0}\right|} d S=0 .
\end{array}\right.
$$


where $\varphi_{0}$ is value of the potential at the surface $S_{0}, \varphi$ is value of the potential at the surface $S_{1}$. The numerical solution of the obtained system of singular integral equations is carried out by the method of discrete singularities. In [6] it is shown that the kernels of integral equations contain complete elliptic integrals of the 1st and 2nd kinds. Since the 2nd-order elliptic integral is a regular function, the standard Gaussian quadratic formula is used for the calculation. An approach base on the characteristic properties of the mean arithmetic geometric value of AGM (a, b), [11] is applied to the elliptic integral of the first kind. External integrals have a logarithmic feature. For their calculating the special Gaussian quadrature formulas [9] are used. The developed method of discrete singularities [12] is applied for the analysis of free and forced vibrations of shell structures.

For solving the forced oscillation problem we consider the Bernoulli equation (2.1) on a free surface. We represent the velocity potential in form (3.1), and write the function describing the position of the free surface as follows:

$$
\zeta=\sum_{k=1}^{M} d_{k}(t) \frac{\partial \varphi_{k}}{\partial \mathbf{n}}
$$

The functions $\varphi_{k}$ are modes of free fluid oscillation in a rigid tank. They are obtained by solving boundary-value problem (2.2). We substitute expressions (3.1) and (3.2) into the Bernoulli integral (2.1), taking into account that

$$
\frac{\partial \varphi_{k}}{\partial \mathbf{n}}=\left.\frac{\chi_{k}^{2}}{g} \varphi_{k}\right|_{s_{0}}
$$

and receive the relation

$$
\sum_{k=1}^{M} \ddot{d}_{k} \varphi_{k}+\sum_{k=1}^{M} \chi_{k}^{2} d_{k} \varphi_{k}\left(1+\frac{a_{z}(t)}{g}\right)+x a_{x}(t)=0
$$

The values $\left.\right|_{k}$ are the frequencies of free oscillation of the fluid in the rigid tank. It should be noted that according to [7, 10], the frequencies and modes of oscillations of the fluid are considered to correspond to certain harmonics, it is also assumed that the velocity potential and the function describing the level of lifting of the free surface. The formulas are presented below

$$
\Phi=\sum_{\alpha=0}^{N} \cos \alpha \theta \sum_{k=1}^{M} \dot{d_{\alpha k}}(t) \varphi_{\alpha k}(r, z), \quad \zeta=\frac{1}{g} \sum_{\alpha=0}^{N} \cos \alpha \theta \sum_{k=1}^{M} \chi_{\alpha k}^{2} d_{\alpha k}(t) \varphi_{\alpha k}(r, 0)
$$

In equality (3.5) the wave number $\zeta$ characterizes the harmonic number, or the number of nodal diameters $[7,10]$.

Of especial importance is a value $\alpha=0$, which determines the axisymmetric fluctuations of the fluid in the rigid reservoir, as well as $\alpha=1$ which corresponds to antisymmetric oscillations.

Let us find the scalar product of equality (3.4) on the function $\varphi_{l}(l=\overline{1, M})$ using orthogonality of eigenmodes. We obtain a non-coupled system of 2 nd order Mathieu differential equations:

$$
\ddot{d}_{k}+\chi_{k}^{2}\left(1+\frac{a_{z}(t)}{g}\right) d_{k}=-a_{x}(t)\left(x, \varphi_{k}\right)
$$

To obtain a solution to the system (3.6), the initial conditions must be set. We use hereinafter

$$
\dot{d}_{1}(0)=0.05, \dot{d}_{k}(0)=0.0, k=\overline{2, M}, d_{k}(0)=0, k=\overline{1, M} \text {. }
$$

\section{Numerical results}

The liquid vibrations in the cylindrical- conical shell are considered. Suppose that $R_{1}=H_{1}=H_{2}=1 \mathrm{~m}$ and $R_{2}=1 \mathrm{~m}$. Let horizontal and vertical accelerations be $a_{x}=a_{1} \cos \omega_{x} t, a_{z}=a_{2} \cos \omega_{z} t$. Timehistories of free surface elevation at different loadings are shown in Fig. 4.1-4.4. Hereinafter the dot points correspond to horizontal excitations $\left(a_{1}=0.1, a_{2}=0\right)$, dash lines correspond to vertical excitations ( $\left.a_{1}=0, a_{2}=1.8\right)$, solid lines in Fig. 4.1 and 4.3 correspond to the free surface elevation due to simultaneous action of vertical and horizontal excitations. 


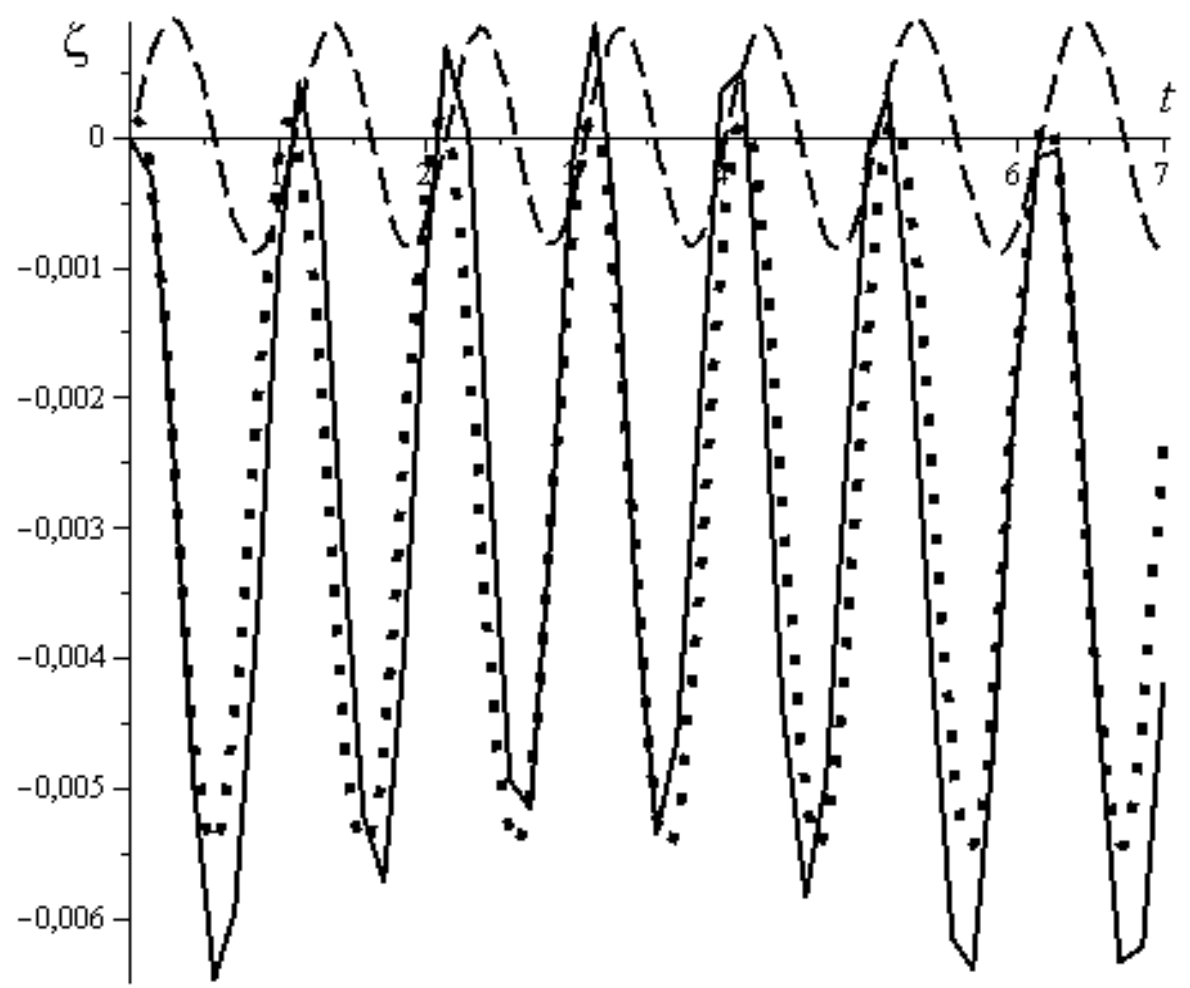

Figure 4.1. Time- histories of free surface elevation at different loadings, $\omega=6.13 \mathrm{~Hz}, \omega_{z}=1.0 \mathrm{~Hz}, \omega_{x}=0.012 \mathrm{~Hz}$.

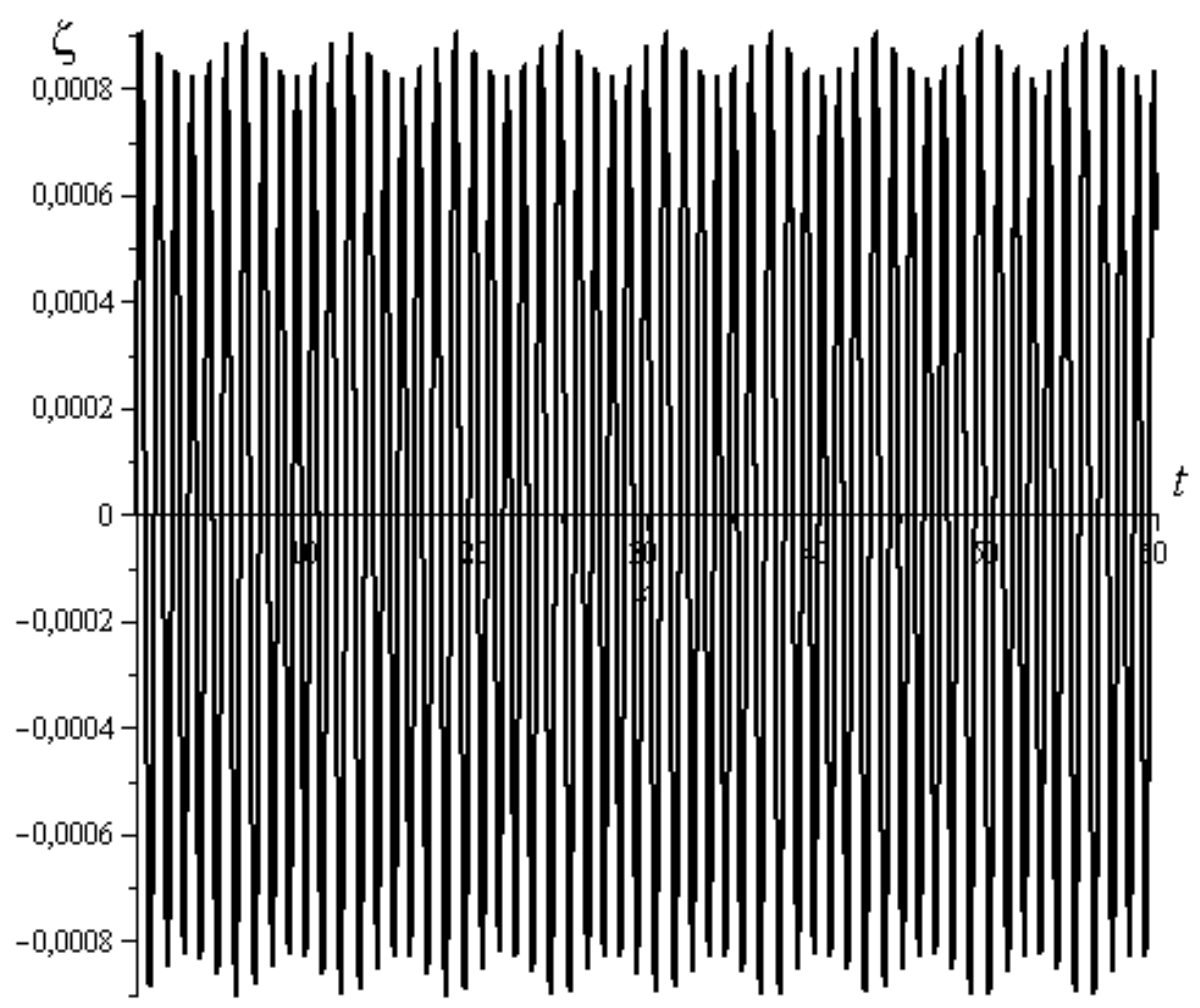

Figure 4.2. Time- history of free surface elevation at vertical loading, $\omega=6.13 \mathrm{~Hz}, \omega_{z}=1.0 \mathrm{~Hz}, a_{2}=1.8$. 


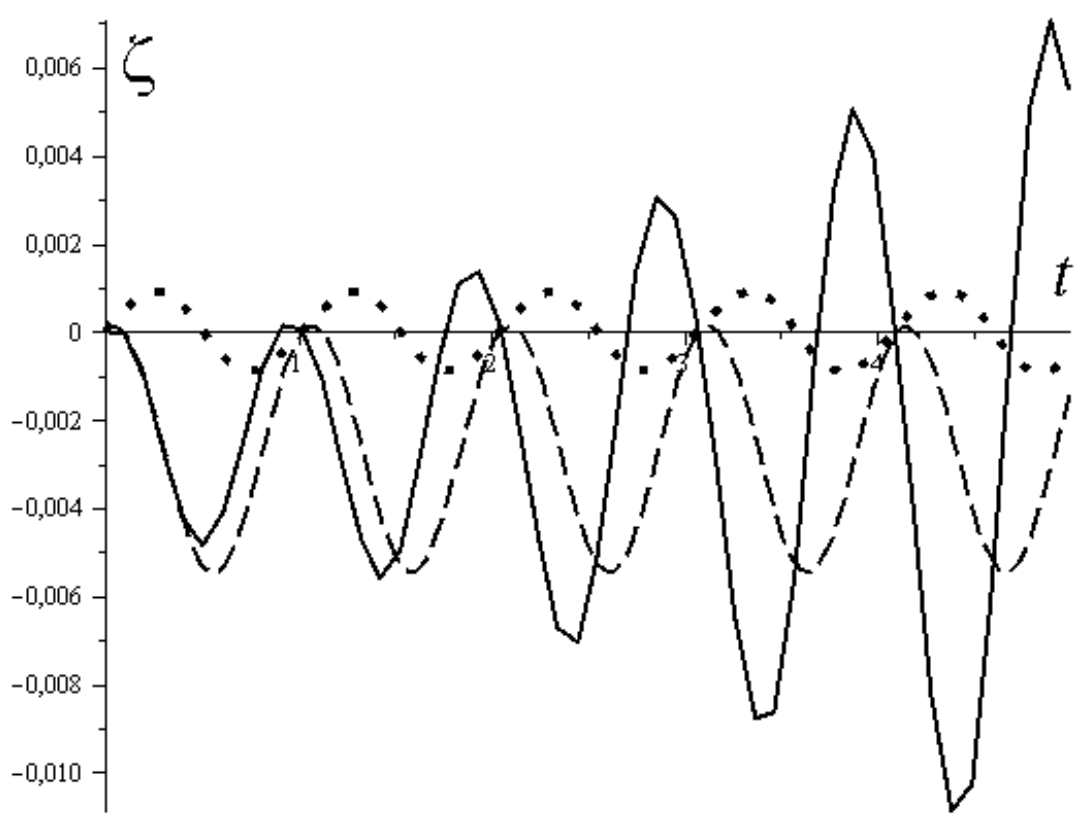

Figure 4.3. Time- histories of free surface elevation at different loadings, $\omega=6.13 \mathrm{~Hz}, \omega_{z}=6.13 \mathrm{~Hz}$, $\omega_{x}=0.012 \mathrm{~Hz}, a_{1}=0.1 ; \quad a_{2}=1.8$.

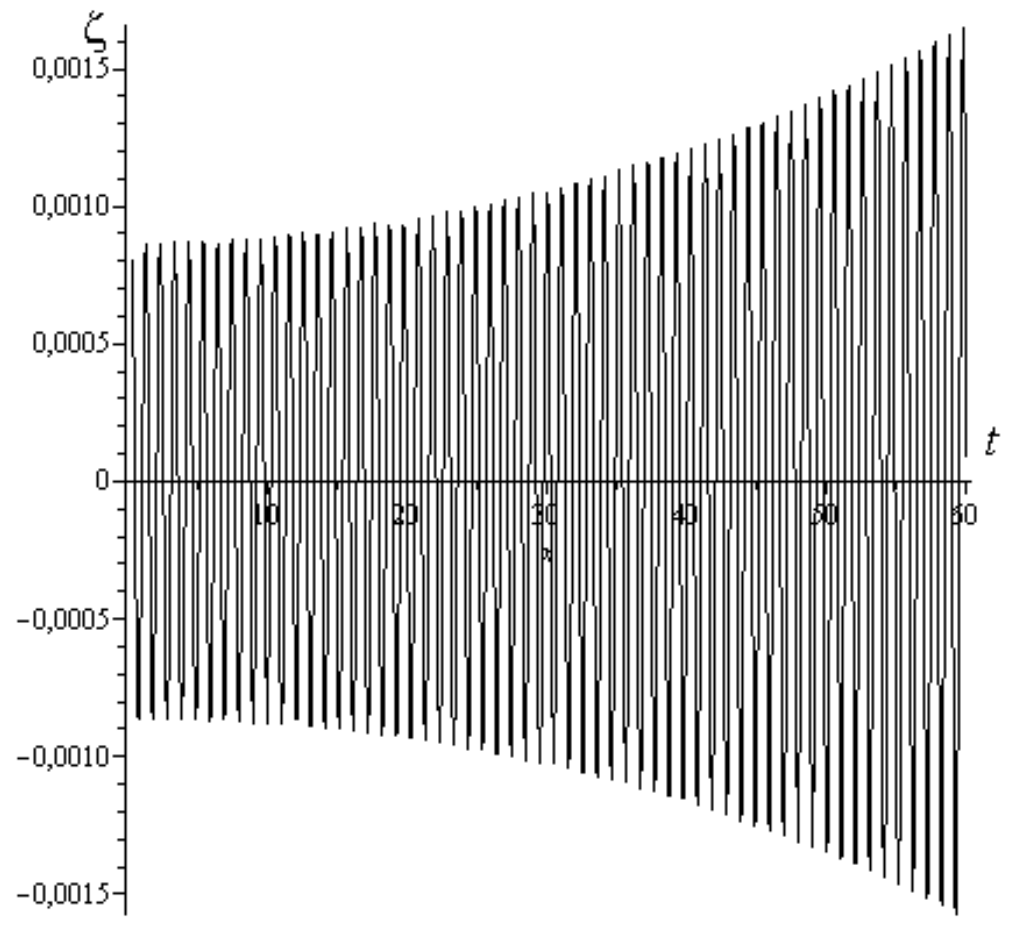

Figure 4.4. Time- history of free surface elevation at vertical loading, $\omega=6.13 \mathrm{~Hz}, \omega_{z}=6.13 \mathrm{~Hz}, a_{2}=1.8$.

The results depicted in Fig. 4.3, 4.4 demonstrate that the parameters of sloshing process correspond to the region of instability.

\section{Conclusions}

The method of estimation of forced vibrations of liquid in the shells of rotation based on the use of the method of boundary integral equations and the Fourier series decomposition has been developed. The integral equations have been solved using the method of discrete singularities. The analysis of the results has shown that the phenomenon of parametric resonance takes place. The joint effect of vertical and horizontal excitations has been considered. 


\section{REFERENCES}

1. R.A. Ibrahim, V.N. Pilipchuck, T. Ikeda., "Recent Advances In Liquid Sloshing Dynamics". Applied Mechanics Reviews, Vol. 54, No. 2, pp. 133-199, 2001.

2. R.A. Ibrahim. Liquid Sloshing Dynamics: textbook. Cambridge University Press, New York, 2005, 948 p.

3. Eseleva E., Gnitko V., Strelnikova E., "Natural oscillations of pressure vessels during interaction with a liquid". Prob. mechanical engineering, №1, pp.105-118, 2006. [in Russian]

4. Gnitko V., Naumenko V., Rozova L., Strelnikova E." Multi-domain boundary element method for liquid sloshing analysis of tanks with baffles". Journal of Basic and Applied Research International, 17(1), pp. 75-87, 2016.

5. Gavrilyuk, I., M. Hermann, Lukovsky I., Solodun O., Timokha, A. "Natural Sloshing frequencies in Truncated Conical Tanks". Engineering Computations, Vol. 25 Iss: 6, pp.518 540, 2008.

6. Gnitko, V., Naumemko, Y., Strelnikova E. "Low frequency sloshing analysis of cylindrical containers with flat and conical baffles". International Journal of Applied Mechanics and Engineering, 22 (4), pp.867-881, 2017.

7. Gnitko, V., Degtyarev, K., Naumenko, V., Strelnikova, E. "Coupled BEM and FEM analysis of fluid-structure interaction in dual compartment tanks". Int. Journal of Computational Methods and Experimental Measurements, Vol.6, No.6, pp. 976-988, 2018.

8. Strelnikova E., Gnitko V., Krutchenko D., Naumemko Y. "Free and forced vibrations of liquid storage tanks with baffles". J. Modern Technology \& Engineering, Vol.3, No.1, pp.15-52, 2018.

9. Brebbia, C.A, Telles, J.C.F \& Wrobel, L.C., Boundary element techniques: theory and applications in engineering: textbook. Springer-Verlag: Berlin and New York, 1984, $464 \mathrm{p}$.

10. Kylynnyk V. Yu., Gnitko V. I., Naumenko Yu. V., Rozova L. V. "Numerical simulation of fluid oscillations in composed shells of rotation at overloads". Applied Mathematical Modeling, N 1., pp. 115-121, 2018. [in Ukrainian]

11. David A. Cox. "The Arithmetic-Geometric Mean of Gauss". L'Enseignement Mathématique, t. 30, pp. $275-330,1984$.

12. Yu. V. Gandel', T. S. Polyanskaya, "Justification of a Numerical Method for Solving Systems of Singular Integral Equations in Diffraction Grating Problems". Differ. Equ, 39:9, pp.12951307, 2003.

\section{ЛІТЕРАТУРА}

1. R.A. Ibrahim, V.N. Pilipchuck, T. Ikeda. Recent Advances In Liquid Sloshing Dynamics. Applied Mechanics Reviews. 2001. Vol. 54, No. 2. pp. 133-199.

2. R.A. Ibrahim. Liquid Sloshing Dynamics:textbook. Cambridge University Press, New York, 2005. $948 \mathrm{p}$.

3. Еселева Е.В., Гнитько В.И., Стрельникова Е.А. Собственные колебания сосудов высокого давления при взаимодействии с жидкостью. Пробл. машиностроения. 2006. №1. C.105-118.

4. Gnitko V., Naumenko V., Rozova L., Strelnikova E. Multi-domain boundary element method for liquid sloshing analysis of tanks with baffles. Journal of Basic and Applied Research International. 2016. 17(1). pp. 75-87.

5. Gavrilyuk, I., M. Hermann, Lukovsky I., Solodun O., Timokha, A. Natural Sloshing frequencies in Truncated Conical Tanks. Engineering Computations. 2008. Vol. 25, Iss: 6. pp. $518-540$.

6. Gnitko, V., Naumemko, Y., Strelnikova E. Low frequency sloshing analysis of cylindrical containers with flat and conical baffles, International Journal of Applied Mechanics and Engineering. 2017. 22 (4). pp.867-881.

7. Gnitko, V., Degtyarev, K., Naumenko, V., Strelnikova, E. Coupled BEM and FEM analysis of fluid-structure interaction in dual compartment tanks. - Int. Journal of Computational Methods and Experimental Measurements. 2018. Vol.6, No.6. pp. 976-988. 
8. Strelnikova E., Gnitko V., Krutchenko D., Naumemko Y. Free and forced vibrations of liquid storage tanks with baffles, J. Modern Technology \& Engineering. 2018. Vol.3, No.1. pp.15-52.

9. Brebbia, C.A, Telles, J.C.F \& Wrobel, L.C., Boundary element techniques: theory and applications in engineering:textbook. Springer-Verlag: Berlin and New York, 1984. 464 p.

10. Килинник В.Ю., Гнітько В.І., Науменко Ю.В., Розова Л.В. Чисельне моделювання коливань рідини в складених оболонках обертання при перевантаженнях. Прикладні питання математичного моделювання. 2018. N 1. S. 115-121.

11. David A. Cox. The Arithmetic-Geometric Mean of Gauss.L'Enseignement Mathématique. 1984. t. 30. pp. $275-330$.

12. Yu. V. Gandel', T. S. Polyanskaya, Justification of a Numerical Method for Solving Systems of Singular Integral Equations in Diffraction Grating Problems, Differ. Equ. 2003. 39:9 pp.12951307.

Kylynnyk Vlada Yurievna - bachelor, student of V. N. Karazin Kharkiv National University; 4 Svobody Sq., Kharkiv, Ukraine, 61022 ; e-mail: vladakylynnyk@gmail.com; ORCID: 0000-0002-06319093.

Kriutchenko Denis Vladinirovich -MSc, post graduate, A.Podgorny Institute of Mechanical Engineering Problems, ul. Pozharskogo, 2/10, Kharkiv, Ukraine, 61046, e-mail: wollydenis@gmail.com; ORCID: 0000-0002-6804-6991.

Naumenko Yury Vytalievich - MSc, post graduate, A.Podgorny Institute of Mechanical Engineering Problems, ul. Pozharskogo, 2/10, Kharkiv, Ukraine, 61046, e-mail: strelea@ukr.net; ORCID: 0000-0001-9058-6727.

Килинник Влада Юрї̈вна - бакалавр, студентка Харківського національного університету ім.В.Н.Каразіна; Площа Свободи 4, Харків, Україна, 61022 ; e-mail: vladakylynnyk@gmail.com; ORCID: 0000-0002-0631-9093.

Крютченко Денис Володимирович - магістр, аспірант Інституту проблем машинобудування ім.А.М.Підгорного, вулю Пожарськогоб 2/10, Харків, Украӥна, 61046, е-таil: wollydenis@gmail.com; ORCID:0000-0002-6804-6991.

Науменко Юрій Віталійович - магістр, аспірант Інституту проблем машинобудування ім.A.М.Підгорного, вулю Пожарськогоб 2/10, Харків, Україна, 61046, e-mail: strelea@ukr.net; ORCID: 0000-0001-9058-6727.

Кыльннык Влада Юрьевна - бакалавр, студентка Харьковского национального университета им.В.Н.Каразина; Площадь Свободы 4, Харьков, Украина 61022 ; етаil:

vladakylynnyk@gmail.com; ORCID: 0000-0002-0631-9093.

Крютченко Денис Владимирович - магистр, аспирант, Институт проблем машиностроения им. А. Н. Подгорного, ул. Пожарского, 2/10, Харьков, Украина, 61046, е-таil: wollydenis@gmail.com; ORCID:0000-0002-6804-6991.

Науменко Юрий Витальевич - магистр, аспирант, Институт проблем машиностроения им. A. Н. Подгорного, ул. Пожарского, 2/10, Харьков, Украина, 61046, e-mail: strelea@ukr.net; ORCID: 0000-0001-9058-6727. 